\title{
TRANSPLANTATION EXPERIMENTS WITH MEDITERRANEAN GORGONIANS
}

\author{
by \\ STEVEN WEINBERG \\ Institute of Taxonomic Zoology, University of Amsterdam, The Netherlands
}

\begin{abstract}
Branches of gorgonians belonging to four different Mediterranean species (Eunicella singularis (Esper), Paramuricea clavata (Risso), Corallium rubrum (Linnaeus) and Lophogorgia ceratophyta (Linnaeus)) were transplanted to different habitats by means of three different methods, and survival and growth rates were observed over periods ranging from three months to over two years. It was concluded that transplantation of animals still fixed on their natural substratum is to be preferred over transplantations involving artificial devices. Transplanted adult branches of all four species tolerate conditions under which the species are not usually encountered. Tolerances or preferences of larval and juvenile phases must account for these discrepancies. Transplants never survived in shallow waters. Algal competition, abrasion and mechanical destruction due to turbulent water conditions, and in some cases high irradiance values are among the lethal factors. In deeper water, sedimentation is also fatal, although in nature some colonies survive under similar conditions.
\end{abstract}

\section{RESUME}

Des branches de gorgones appartenant à quatre espèces méditerranéennes (Eunicella singularis (Esper), Paramuricea clavata (Risso), Corallium rubrum (Linnaeus) et Lophogorgia ceratophyta (Linnaeus)) furent transplantées vers des habitats divers à l'aide de trois méthodes différentes, et leurs vitesses de croissance et chances de survie furent suivies pendant des périodes allant de trois mois à deux ans. Il en résulte que la méthode qui consiste à transplanter des individus sur leur substrat naturel est préférable par rapport aux méthodes où un support artificiel est employé. Les branches adultes des quatre espèces toléraient toutes des circonstances dans lesquelles les espèces ne sont pas rencontrées normalement. Ce phénomène ne peut être expliqué que par les tolérances ou préférences des stades larvaires ou juvéniles. Les branches transplantées n'ont jamais survécu dans les eaux proches de la surface. Parmi les causes de leur mort, la concurrence des peuplements algaux est très importante, ainsi que l'érosion ou la destruction mécanique dans ces eaux turbulentes, alors que dans quelques cas la forte irradiance était léthale. Dans les stations profondes, la mort survenait après un recouvrement par sable ou débris animaux, quoique dans les conditions naturelles des colonies arrivent à survivre dans des conditions semblables.

\section{INTRODUCTION}

Benthic invertebrate communities are not randomly distributed. In many cases a depth-dependent zonation has been demonstrated (Roos, 1964; Loya,
1972; Schmidt, 1972; Castric-Fey et al., 1973; Bak, 1975; Van den Hoek et al., 1975; Wedler, 1975; Burla et al., 1976; Camp, 1976; Benayahu \& Loya, 1977; Done, 1977; Wiedenmayer, 1977), and frequently distribution within each zone is patchy, mainly due to discontinuities in environmental parameters (Lewis, 1974; Weinberg, 1975, 1978; Dana, 1976). Irrespective whether populations occur in easily recognizable depth-zonated belts, or rather in patches, several physical parameters have been demonstrated to be the cause of these distributions.

One of the most important factors is submarine irradiance (Roos, 1967; Harmelin, 1969; Chardy, 1970; True, 1970; Zander \& Heymer, 1970, 1977; Duclaux \& Lafargue, 1972; Jaubert \& Vasseur, 1973, 1974; Kinzie, 1973; Schuhmacher, 1973; Boutler et al., 1974; Gamulin-Brida, 1974; Grigg, 1974; Wedler, 1975; Weinberg, 1975, 1978; Dana, 1976; Zander \& Jelinek, 1976). Other factors are sedimentation (Chardy, 1970; Weinberg, 1978) and water movement (Wedler, 1975; Geister, 1977; Wiedenmayer, 1977).

Mediterranean gorgonians (Anthozoa: Octocorallia) conform to this general pattern. Eunicella singularis (Esper) is a rather photophilous species, although it is not found in turbulent surface conditions, and it thrives on horizontal or gently sloping sediment-covered bottoms (Laubier, 1966; Gamulin-Brida, 1974; Carpine \& Grasshoff, 1975; Weinberg, 1978, 1979a). Lophogorgia ceratophyta (Linnaeus) occurs in approximately the same conditions as the previous species, although generally deeper (Laubier, 1966; Carpine \& Grasshoff, 1975; Weinberg, 1978, 1979a). Paramuricea clavata (Risso) is a sciaphilous species typical for vertical and overhanging shaded surfaces, although in deeper water it may also occur on more or less horizontal bottoms (Laubier, 1966; True, 1970; 
Fredj, 1972; Schmidt, 1972; Gamulin-Brida, 1974; Carpine \& Grasshoff, 1975; Weinberg, 1978, 1979a). Finally, Corallium rubrum (Linnaeus) is known from extremely dark places, often occurring on the ceilings of caves, and it may be encountered as deep as 280 metres (Laborel \& Vacelet, 1961; Laubier, 1966; Riedl, 1966; Barletta et al., 1968; True, 1970; Reyss, 1971; Fredj, 1972; Jaubert, 1972; Gamulin-Brida, 1974; Carpine \& Grasshoff, 1975; Weinberg, 1978, 1979a).

The existence of a typical niche for each species may be the result of the preferences of the mobile planula larvae if these settle and metamorphose only in places where a well defined set of environmental conditions is encountered. In order to check this assumption with some of the previously mentioned species, I undertook laboratory experiments with planulae of E. singularis and C. rubrum, thereby focusing mainly on light-dependent behaviour (Weinberg, 1979b). The results were rather divergent. Larvae of $E$. singularis invariably were photopositive, which explains at least part of the distribution pattern found in nature, although the question remains as to why these animals are not found in shallow water. The larvae of C. rubrum were entirely indifferent to light conditions, an unexpected result, since the adults live exclusively in dark places.

In the present paper an attempt is made to verify whether the distributions as observed in nature are due to tolerance of the adult colonies. For this purpose, branches of adult and juvenile colonies were transplanted to places where the environmental conditions differed from those of their typical habitats, while in control experiments transplantations were carried out within the typical habitat of each species. The four previously mentioned species were used in these experiments.

\section{MATERIAL AND METHODS}

The transplantation experiments were all carried out near Banyuls-sur-Mer (southern France). Because of the technical difficulties involved in transplanting soft Octocorallia like Stolonifera or Alcyonacea, and the problems arising when attempting to measure these contractile forms (Roushdy, 1962 ), only rigid Gorgonacea were used in the present experiments, viz. the following species:

Eunicella singularis (Esper, 1794)

Paramuricea clavata (Risso, 1826)

Corallium rubrum (Linnaeus, 1758)

Lophogorgia ceratophyta (Linnaeus, 1758).
Transplantation experiments consisted of bringing cuttings of uniform length, but also sometimes entire juvenile colonies, to habitats in which the species involved are not usually encountered. Since submarine irradiance is an extremely important parameter in benthic ecology, values were calculated for each station according to Weinberg \& Cortel-Breeman (1978). In control experiments, the gorgonians were transplanted within their own niche, in order to check on the effects of the transplantation method itself. At irregular intervals the lengths of the branches were measured, and the appearance and growth of sidebranches monitored. Three different transplantation techniques have been used, which will be briefly outlined. Colonies were always collected in habitats where the species reach high population densities. For $E$. singularis and $L$. ceratophyta these optimum habitats were horizontal bottoms at about $20 \mathrm{~m}$ depth, for $P$. clavata vertical surfaces at about $25 \mathrm{~m}$ depth, and for $C$. rubrum small holes at about $35 \mathrm{~m}$ depth.

\section{Experiments with concrete blocks}

The basic unit in these experiments, which were started in June 1976, was a clamp (fig. 1) made of a hard PVC-tube in which two incisions were made, yielding a flexible lip. Around the top of this tube a PVC-collar was fit and by means of a brass screw the lip could be tightened upon a cutting of a gorgonian branch. A uniform length was left protruding over the rim of the collar. Fast positioning was

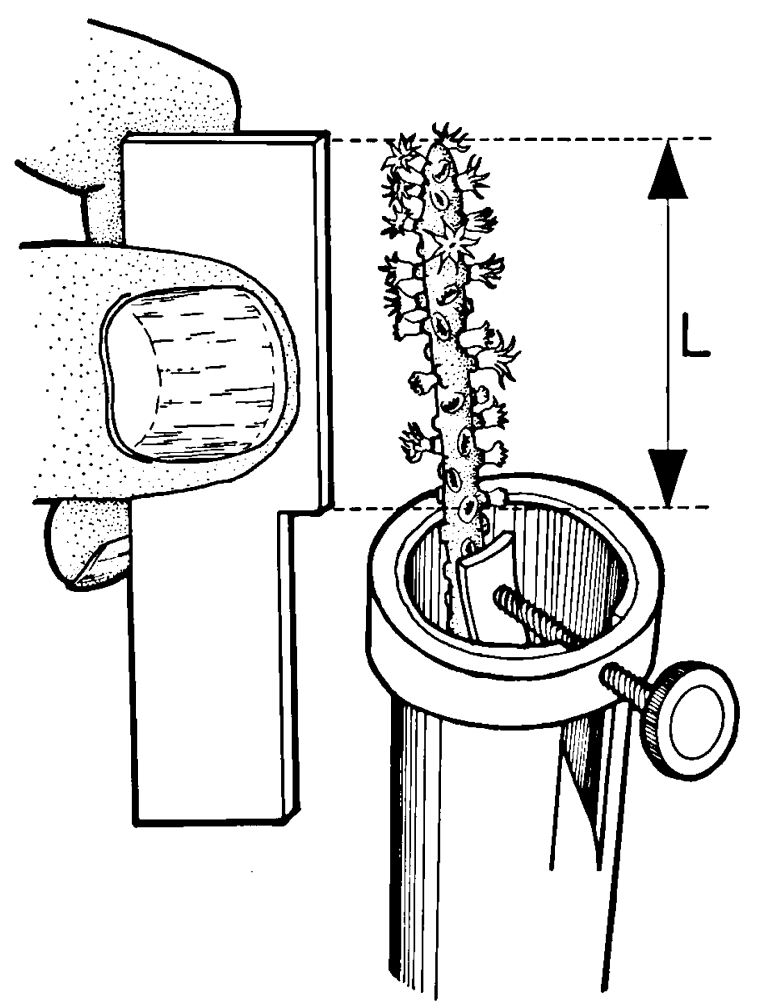

Fig. 1. Detail of a PVC-clamp as used in the first series of transplantation experiments. While the protruding part of the branch is held at a pre-selected length $L$ by means of a standard-gauge, the lip is tightened upon the branch by means of a screw. 


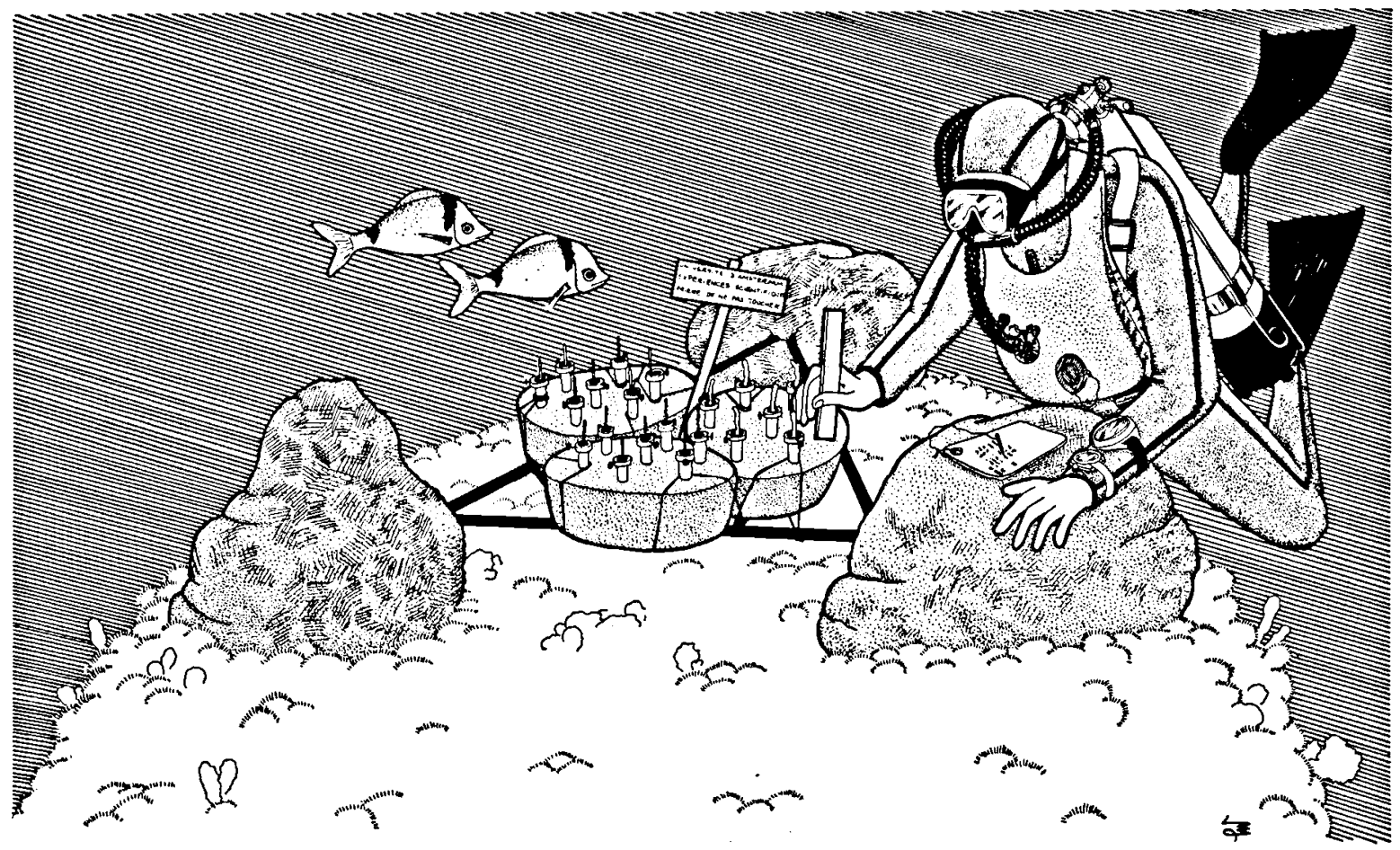

Fig. 2. Example of a station (Cap Béar, $-10 \mathrm{~m}$ ) in the first series of transplantation experiments. Clamps are cast in concrete cylinders, which are attached to an iron frame, the corners of which are sunk into three gunny sacks filled with concrete. Each cylinder bears seven branches of a different species (E. singularis; $P$. clavata; $C$. rubrum). The diver carries out length measurements with an ordinary plastic ruler, while notes are made on a Formica slate by means of an attached solid carbon pencil.

obtained by means of a standard gauge (fig. 1). A disadvantage of this system, which was only discovered later on, resides in its rigidity. At the point of contact with the clamp, the living tissues will die, thus exposing the bare gorgonian axis, and the branches will remain rather loose in the clamps, causing branches to disappear or sometimes to sink deeper into the tubes. In spite of a regular re-tightening of the screws, many branches were lost in this way. Seven of these clamps were cast together in a cylindrical concrete block $(\varnothing=40 \mathrm{~cm}, \mathrm{~h}=10 \mathrm{~cm})$. A total of 14 blocks was made, and three of these blocks used per station (in one station only two blocks), each block bearing 7 cuttings of a different species E. singularis, $P$. clavata and $C$. rubrum). So far, the method resembles the one used by Van ' $t$ Hof (personal communication) during similar experiments in Curaçao (West Indies). Because the Mediterranean, and especially the Banyuls area with its strong northern winds ("Tramontane") is much rougher than the Caribbean, I decided to add weight in order to anchor the blocks to the bottom. Fig. 2 shows one typical station (Cap Béar, $-10 \mathrm{~m}$ ). Three gunny sacks filled with a mixture of dry cement and sand were lowered by means of inflatable "parachutes". Once into place, at the corners of an equilateral triangle with sides of about $150 \mathrm{~cm}$, a small hole was punctured into each sack, and a welded metal frame stuck into the now liquid concrete. After a few days the concrete in the sacks had hardened out, and the concrete blocks with the clamps were firmly attached to the metal frame by means of nylon rope. The total weight of the installation was about $200 \mathrm{~kg}$ on land (100 kg under water). In spite of this, two installations were swept away during storms in the extremely rough waters off Cap Béar. The first one, installed on a ledge at $5 \mathrm{~m}$ depth, lasted less than 3 months. The other, at $10 \mathrm{~m}$ depth, which was described above, was swept away after 8 months.

\section{Experiments with PVC-racks}

As weight would not keep the installations in place in turbulent waters, I decided for another approach. For this purpose very light and somewhat flexible PVC-racks were made, offering very little resistance to water movement. These racks were attached with nylon rope to steel nails driven into the bottom, or to natural holdfasts whenever available. Instead of the clamps used in the concrete blocks, 30 plastic clothespegs were attached to each rack (fig. 3), which had the advantage of automatically tightening themselves on a branch in case of tissue loss. Experiments were initiated in Abril 1977 and carried out with onlv two species $E$. singularis and $P$. clavata). The standard gauge (fig. 1) was again used for fast positioning of the branches at a chosen length. As was expected, this system worked much better than the previous one. However, even in this case some racks were eventually destroyed, and branches kept disappearing from the clothespegs, sometimes due to fatigue of the horny axis, the lower parts of which were held too rigidly in the clothespins, while the top kept swaying in the swell. 


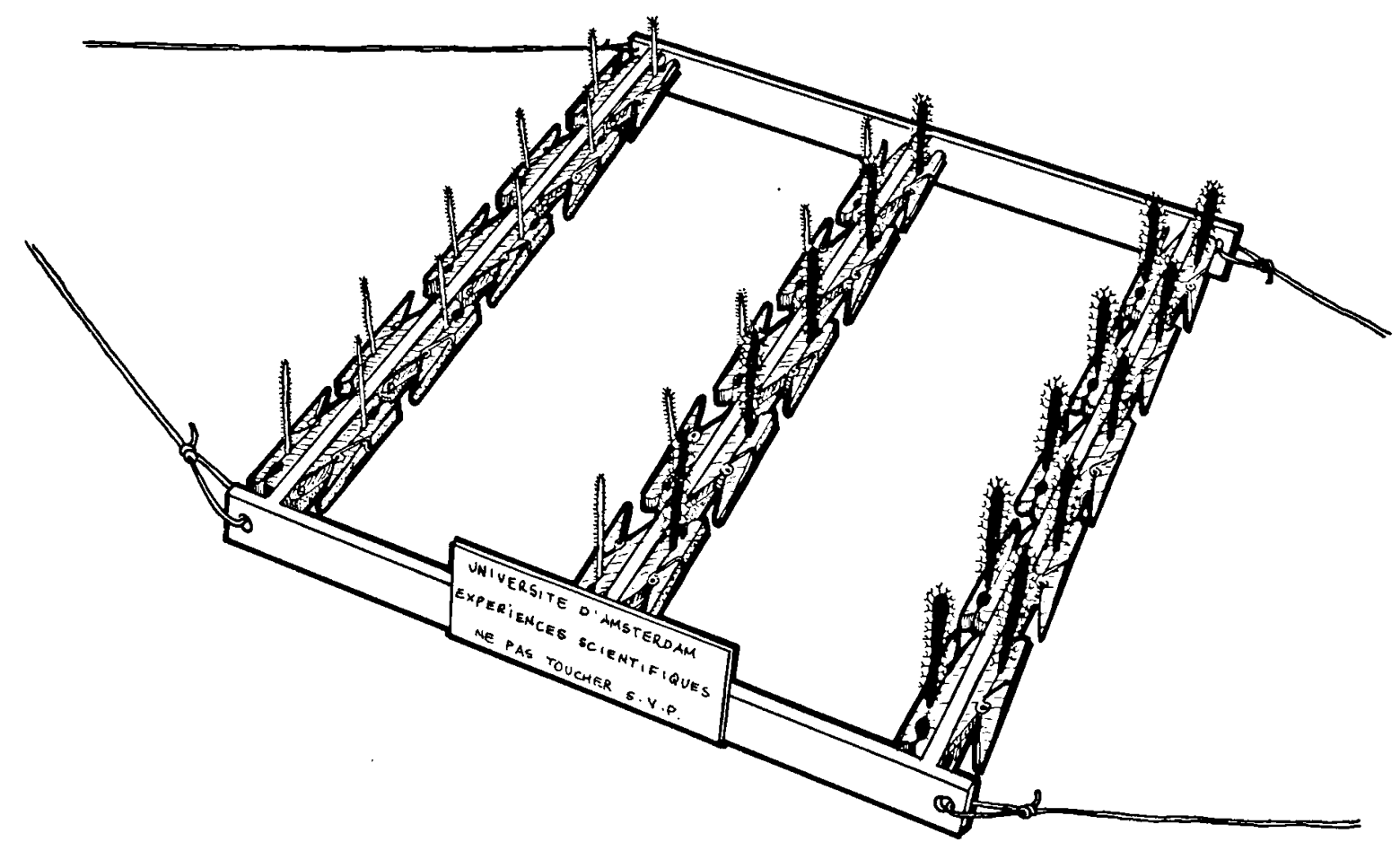

Fig. 3. PVC-rack as used in the second series of transplantation experiments. The very light and flexible rack is held into place by means of nylon ropes attached to its corners. Each rack bears 30 clothespegs, in which branches are installed at pre-selected lengths by means of a standard-gauge. Each rack bears fifteen branches of E. singularis and fifteen of $P$, clavata.

\section{Experiments with transplanted stones}

In a final experiment, stones were collected, bearing mainly juvenile colonies. These stones were firmly attached to heavy metal racks by means of nylon rope, and the racks installed in different stations. The aim of these experiments was to test the tolerances of naturally attached colonies, especially juvenile ones. No technical problems were encountered during these experiments, which started in December 1977, and involved $E$. singularis, $L$. ceratophyta and $P$. clavata. Place, shape and dimensions of the colonies were carefully drawn, and any change in dimension, appearance of new branchlets, and disappearance of colonies was thus monitored.

\section{RESULTS}

\section{Eunicella singularis}

a. Experiments with concrete blocks

i. Cap Béar, $-5 \mathrm{~m}$. Irradiance: $11000 \mathrm{cal} \mathrm{cm}^{2}$ year ${ }^{-1}$. Experiment started on 9 June 1976. After 77 days a slight negative growth $\left(-5.8 \mathrm{~mm}\right.$ year $\left.{ }^{1}\right)$ was observed, possibly due to the branches sinking into the clamps. After 97 days the station was found destroyed by a gale.

ii. Cap Béar, $-10 \mathrm{~m}$. Irradiance: $5100 \mathrm{cal} \mathrm{cm}^{-2}$ year ${ }^{-1}$. Experiment started on 9 June 1976. After
161 days 4 branches (out of the initial 7) remained in place, and 12 sidebranches had formed. Average growth was positive $\left(28.5 \mathrm{~mm}\right.$ year $\left.{ }^{-1}\right)$. Three months later, on 18 February 1977 , the installation was found destroyed by a gale, lying in a cleft $3 \mathrm{~m}$ deeper. On 6 December 1977, 545 days after the experiment was started, one branch was found still alive. Although it had apparently grown only $6 \mathrm{~mm}$ during the entire period, it might have been damaged in the storm(s).

iii. Cap Béar, $-20 \mathrm{~m}$. Irradiance: $1375 \mathrm{cal} \mathrm{cm}^{-2}$ year ${ }^{1}$. Experiment started on 9 June 1976. After 131 days, 4 branches remained in place, and average growth was positive $\left(25.7 \mathrm{~mm}^{-1}\right.$ year $\left.^{-1}\right)$. One month later, on 17 November 1976, only 2 damaged branches remained, and a new experiment was started. Although branches disappeared from this experiment also ( 7 remained on 26 November 1976; 5 on 16 June 1977; 3 on 6 December 1977 and 2 on 20 June 1978), the remaining branches kept growing for 571 days (average of $17.4 \mathrm{~mm}$ year $^{-1}$ ). At this time 4 lateral branchlets, in lengths ranging from 7 to $34 \mathrm{~mm}$ had formed as well. 
iv. Cap Rédéris, on top of isolated boulder, $-24 \mathrm{~m}$. Irradiance: $850 \mathrm{cal} \mathrm{cm}^{-2}$ year $^{-1}$. Experiment started on 11 June 1976. Although no branches were lost for 130 days, their lengths remained virtually the same during this period.

v. Cap Rédéris, at the foot of a vertical wall, $-24 \mathrm{~m}$. Irradiance: $100 \mathrm{cal} \mathrm{cm}^{-2}$ year $^{-1}$. Experiment started on 11 June 1976. No branches were lost during the first 74 days, but after 102 days 4 branches remained. Length had increased regularly but slowly ( $11.6 \mathrm{~mm}$ year $^{-1}$ ). Four weeks later only 3 branches were found, which had sunk for some $\mathrm{mm}$ into their clamps, and the experiment was terminated.

\section{b. Experiments with PVC-racks.}

i. Ile Grosse, $-2 \mathrm{~m}$. Irradiance: $20000 \mathrm{cal} \mathrm{cm}^{-2}$ year ${ }^{-1}$. Experiment started on 6 April 1977. After 58 days the tops of all branches had disappeared from the clothespegs, although the lower parts of these branches, protruding from the undersides of the clothespegs were still alive. New branches were installed in July. Five months later, the rack was found detached and destroyed by wave action, but Mr. Christophe Gros (Laboratoire Arago) reported that prior to the storm, the branches were still alive.

ii. Ile Grosse, on the pipe transporting seawater to the laboratory, $-3 \mathrm{~m}$. Irradiance: $16500 \mathrm{cal}$ $\mathrm{cm}^{-2}$ year ${ }^{-1}$. Experiment started on 6 April 1977. After 61 days, 9 out of the initial 15 branches were still alive, but their growth very slow $(2.6 \mathrm{~mm}$ year-1). The algae (mainly Codium dichotomum (Hudson), Dictyota dichotoma (Hudson) and Cystoseira spp.) which grow abundantly in this place seem to damage the gorgonian branches by friction. In July 1977, a new experiment was started. Five months later, only 6 branches remained, and growth rate was again quite slow ( $5.8 \mathrm{~mm}$ year ${ }^{-1}$ ). Many branches had broken off at their bases, probably due to material fatigue in the permanent swell at this spot. One year later, in July 1978, all gorgonians were dead, smothered by an algal turf layer.

iii. Grotte de Béar, entrance, $-3 \mathrm{~m}$. Irradiance: $5000 \mathrm{cal} \mathrm{cm}^{-2}$ year ${ }^{-1}$. Experiment started on 5 April 1977. After 61 days, nearly all (13) branches remained in place, growing steadily $(8.7 \mathrm{~mm}$ year $^{-1}$ ). After 442 days, the rack had not moved, but was found to be free of gorgonians and overgrown by an algal turf layer.

iv. Grotte de Béar, rear, $-1 \mathrm{~m}$. Irradiance: $13 \mathrm{cal}$ $\mathrm{cm}^{-2}$ year-1. Experiment started on 5 April 1977. After 61 days, 11 branches remained in place, growing steadily (10.4 mm year-1). After 442 days, the rack was found to have been destroyed by wave action.

v. Ile Grosse, $-15 \mathrm{~m}$. Irradiance: $2600 \mathrm{cal} \mathrm{cm}^{-2}$ year-1. Experiment started on 6 April 1977. After 58 days, 13 branches remained, growing steadily ( $10.2 \mathrm{~mm}$ year ${ }^{-1}$ ). After 240 days, only 6 branches remained, but the average growth rate had hardly changed (11.6 mm year ${ }^{-1}$ ). In July 1978, 453 days after the experiment was started, the rack was found destroyed by a log which had rolled over it during a storm. Only 2 damaged branches remained, but they were still alive.

vi. Cap Béar, $-20 \mathrm{~m}$. Irradiance: $1375 \mathrm{cal} \mathrm{cm}^{-2}$ year-1. Experiment started on 6 April 1977. Branches kept disappearing during the experiment (11 remained on 16 June 1977; 3 on 6 December $1977 ; 1$ on 22 June 1978), but the average growth rates of the branches still in place remained quite constant over the entire 434 day period $(8.9 \mathrm{~mm}$ year $^{-1}$ ).

vii. Cap Rédéris, on top of isolated boulder, $-24 \mathrm{~m}$. Irradiance: $850 \mathrm{cal} \mathrm{cm}^{-2} \mathrm{year}^{-1}$. Experiment started on 7 April 1977. Growth was very slow ( $0.9 \mathrm{~mm}$ year ${ }^{-1}$ ) during the first 246 days, after which 8 branches remained. During the subsequent 190 days 5 branches disappeared, but growth rates of the remainder increased to an average of 7.1 mm year ${ }^{-1}$.

viii. Cap Rédéris, in crevice under isolated boulder, $-25 \mathrm{~m}$. Irradiance: $20 \mathrm{cal} \mathrm{cm}^{-2}$ year ${ }^{-1}$. Experiment started on 5 April 1977. On 19 July 1977 no growth had occurred, but many branches were damaged by sediment or debris. The rack was therefore moved to the foot of a vertical wall (see section III.1.a.v.), where many branches disappeared again, while the average growth rate of the branches still in place remained very low ( 1.8 $\mathrm{mm}$ year ${ }^{-1}$ ) over the following 68 days.

ix. Cap Rédéris, lower part of vertical wall, $-23 \mathrm{~m}$. Irradiance: $125 \mathrm{cal} \mathrm{cm}^{-2} \mathrm{year}^{-1}$. Experiment started on 4 April 1977. During the first 68 days, 
average growth rate was $5.9 \mathrm{~mm}^{-1}$ year $^{-1}$, while 11 branches remained in place. After 247 days, only 2 branches remained, while growth rate was 8.1 $\mathrm{mm}$ year ${ }^{-1}$. After 438 days, only 1 diminished branch remained in the rack.

x. Cap Rédéris, under overhanging rock, -26 m. Irradiance: $8 \mathrm{cal} \mathrm{cm}^{-2}$ year-1. Experiment started on 4 April 1977. After 85 days, all the branches were dead, the rack being half buried under coarse sand and debris of animal origin (dead shells, bryozoans, etc.). The experiment was started again on 19 July 1977. Nearly five months later, half the rack was buried again, and many branches were destroyed. Three branches showed positive growth, however (10.3 mm year-1). On 19 June 1978, nearly a year after the experiment was restarted, the rack was found tumbled over (probably by divers), and although damaged, some branches were still alive.

\section{c. Experiments with transplanted stones.}

i. Ile Grosse, on the concrete pipe transporting seawater to the laboratory aquarium, $-3 \mathrm{~m}$. Irradiance: $16500 \mathrm{cal} \mathrm{cm}^{-2}$ year-1. Experiment started with 26 juvenile, unbranched colonies on 9 December 1977. In July 1978, after 193 days, all the colonies were dead, smothered by algal turf.

ii. Grotte de Béar, $-3 \mathrm{~m}$. Irradiance: $80 \mathrm{cal}$ $\mathrm{cm}^{-2}$ year ${ }^{-1}$. Experiment started with 41 (side)branches on 9 December 1977. In June 1978, after 194 days, 27 (side)branches remained alive, their average growth rate being $14.1 \mathrm{~mm}^{-1}$ year $^{-1}$.

iii. Cap Béar, $-20 \mathrm{~m}$. Irradiance: $1375 \mathrm{cal} \mathrm{cm}^{-2}$ year ${ }^{-1}$. Experiment started on 9 December 1977 with 30 branches. After 195 days, 25 branches could be measured, of which 8 were newly formed sidebranches. Average growth rate was rather high (22.4 $\mathrm{mm}$ year $^{-1}$ ).

iv. Cap Rédéris, under overhanging rock, -26 m. Irradiance: $8 \mathrm{cal} \mathrm{cm}^{-2}$ year ${ }^{-1}$. Experiment started on 9 December 1977 with 42 (side)branches. After 192 days, many branches were damaged by sediment and debris. However, 21 (side)branches were unharmed, two of them being new sidebranches. Average growth rate was high (20.6 $\mathrm{mm}$ year $^{-1}$ ).

\section{Paramuricea clavata}

a. Experiments with concrete blocks

i. Cap Béar, $-5 \mathrm{~m}$. Irradiance: $11000 \mathrm{cal} \mathrm{cm}^{-2}$ year ${ }^{-1}$. Experiment started on 16 June 1976. The branches dwindled rapidly during the first 70 days $\left(-85.3 \mathrm{~mm}\right.$ year $\left.^{-1}\right)$. On 14 September 1976 the installation was found to have been destroyed by a storm.

ii. Cap Béar, $-10 \mathrm{~m}$. Irradiance: $5100 \mathrm{cal} \mathrm{cm}^{-2}$ year-1. Experiment started on 16 June 1976. After three months the branches were found to be growing steadily ( $11.0 \mathrm{~mm}$ year $^{-1}$ ). After 154 days, some of the branches were shorter, probably due to sinking into the clamp tubes. They were alive and healthy, however. By 18 February 1977 the installation had been destroyed by a storm.

iii. Cap Béar, $-20 \mathrm{~m}$. Irradiance: $1375 \mathrm{cal} \mathrm{cm}^{-2}$ year-1. Experiment started on 16 June 1976. Average growth rates were quite high during the first five months of the experiment, when all 7 branches remained in the clamps: $29.6 \mathrm{~mm}^{-1}$ year $^{-1}$ after 154 days. Exactly one year after the experiment was started, only 4 branches remained, which had formed 17 sidebranches, with lengths from 4 to $48 \mathrm{~mm}$. More than two years (736 days) after starting the experiment, two branches were still alive and healthy, with 6 sidebranches from 6 to $27 \mathrm{~mm}$. Average growth rates had slowed down to $9.1 \mathrm{~mm}$ year ${ }^{-1}$. Another, parallel, experiment was started on 6 December 1976. After 192 days, these branches were growing at an average rate of 13.0 mm year $^{-1}$.

iv. Cap Rédéris, at the foot of a vertical wall, $-24 \mathrm{~m}$. Irradiance: $100 \mathrm{cal} \mathrm{cm}^{-2}$ year $^{-1}$. Experiment started on 11 June 1976. After 130 days all 7 branches were still alive, but their lengths remained rather stable. On 16 June 1978, after more than two years, one branch was still alive and healthy, although it had partly sunk into the clamp, making further growth measurements impossible.

\section{b. Experiments with PVC-racks}

i. Ile Grosse, $-2 \mathrm{~m}$. Irradiance: $20000 \mathrm{cal} \mathrm{cm}^{-2}$ year ${ }^{-1}$. Experiment started on 6 April 1977. After 58 days, all branches had disappeared from the clothespegs. New branches were installed in July 1977, but they died soon after. 
ii. Ile Grosse, on the pipe carrying seawater to the laboratory, $-3 \mathrm{~m}$. Irradiance: $16500 \mathrm{cal} \mathrm{cm}^{-2}$ year ${ }^{-1}$. Experiment started on 6 April 1977. Two months later, all branches were dead, apparently suffering from the friction of algal fronds. A new series was installed in July 1977, and in December these branches had died also, the bare axis of most branches still in place in the clothespegs.

iii. Grotte de Béar, entrance, $-3 \mathrm{~m}$. Irradiance: $5000 \mathrm{cal} \mathrm{cm}^{-2}$ year $^{-1}$. Experiment started on 5 April 1977. After 61 days nine slowly growing branches remained in the rack ( $2.6 \mathrm{~mm}^{-1}$ year $\left.^{-1}\right)$. After 442 days the rack was devoid of gorgonians and overgrown by an algal turf layer.

iv. Grotte de Béar, rear, $-1 \mathrm{~m}$. Irradiance: $13 \mathrm{cal}$ $\mathrm{cm}^{-2}$ year-1. Experiment started on 5 April 1977. Although only four branches remained after 61 days, they were growing slowly $\left(4.5 \mathrm{~mm}^{-\mathrm{mear}^{-1}}\right)$. After $\mathbf{4 4 2}$ days, the rack was found dislodged and destroyed.

v. Ile Grosse, $-15 \mathrm{~m}$. Irradiance: $2600 \mathrm{cal} \mathrm{cm}^{-2}$ year $^{-1}$. Experiment started on 6 April 1977. During the first two months, only five branches disappeared, and average growth rates were rather high (18.9 mm year-1). After 240 days only five branches remained, and average growth rates had slowed down to $7.9 \mathrm{~mm}^{-1}$ year $^{-1}$. More than a year after the experiment was started, the rack was found partially destroyed after a storm, when a huge $\log$ was rolled over the station. However, the two remaining branches, although damaged, were still alive, and average growth rates still positive ( $3.2 \mathrm{~mm}^{-1}$ year $\left.^{-1}\right)$.

vi. Cap Béar, $-20 \mathrm{~m}$. Irradiance: $1375 \mathrm{cal} \mathrm{cm}^{-2}$ year-1. Experiment started on 6 April 1977. After 73 days only seven branches remained in the rack, average growth being $3.6 \mathrm{~mm}$ year ${ }^{-1}$. Another 6 months later only one branch remained, and 434 days after the experiment was started this branch had also disappeared.

vii. Cap Rédéris, on top of an isolated boulder, $-24 \mathrm{~m}$. Irradiance: $850 \mathrm{cal} \mathrm{cm}^{-2} \mathrm{year}^{-1}$. Experiment started on 7 April 1977. After 66 days, 11 of the branches remaining in the rack were growing positively at an average rate of $14.1 \mathrm{~mm}^{-1}$ year $^{-1}$. After 246 days, 15 branches, including some new sidebranches, were growing positively, at an average rate of $9.6 \mathrm{~mm}^{-1} \mathrm{ear}^{-1}$. After 436 days, the average growth rate of 13 branches was $8.8 \mathrm{~mm}$ year' ${ }^{-1}$.

viii. Cap Rédéris, in cleft under huge boulder, $-25 \mathrm{~m}$. Irradiance: $20 \mathrm{cal} \mathrm{cm}^{-2}$ year-1. Experiment started on 5 April 1977. In July 1977 no growth had occurred, but many branches were damaged by sand or debris. The rack was therefore moved to the foot of a vertical wall (see section III.1.a.v.), where many branches disappeared, but where average growth was $6.8 \mathrm{~mm}$ year-1, as measured on the 7 remaining branches after 68 days.

ix. Cap Rédéris, lower part of vertical wall, -23 m. Irradiance: $125 \mathrm{cal} \mathrm{cm}^{-2}$ year $^{-1}$. Experiment started on 4 April 1977. After 68 days the remaining 13 branches were growing steadily $(10.7 \mathrm{~mm}$ year ${ }^{-1}$ ), but after 247 days only 5 branches showed positive growth $\left(2.4 \mathrm{~mm}\right.$ year $\left.^{-1}\right)$ and after 438 days the average growth rate measured over 8 positively growing branches (apparently 3 had recovered from damage done to them previously) was a low $1.3 \mathrm{~mm}^{-1}$ year $^{-1}$.

x. Cap Rédéris, under overhanging rock, $-26 \mathrm{~m}$. Irradiance: $8 \mathrm{cal} \mathrm{cm}^{-2}$ year-1. Experiment started on 4 April 1977. After three months, the rack was found half buried under coarse sand and debris, and the animals in it were dead. On 19 July 1977 a new experiment was started, and 142 days later, although again many branches had perished due to sediment, five branches showed positive growth ( $7.7 \mathrm{~mm}$ year $\left.{ }^{-1}\right)$.

\section{c. Experiments with transplanted stones}

In only one of these experiments, the one carried out at Cap Rédéris under the overhanging rock at $-26 \mathrm{~m}$ (irradiance $8 \mathrm{cal} \mathrm{cm}^{-2}$ year-1), was a young $^{-1}$ ) colony of Paramuricea, growing on a tunicate (Microcosmus sp.): The colony consisted of 7 branches. After 192 days, all these branches had grown, and a new one had appeared. Average growth over these 8 branches yielded $12.5 \mathrm{~mm}$ year'1.

\section{Corallium rubrum}

This species was used only during the first series of experiments, namely the one with the concrete blocks. The branches are quite brittle, and since most of them kept breaking with the progression 
of time, no other experiments were carried out. Since growth rates were only negative, comparison of growth rates will not yield significant results. However, survival rates do.

i. Cap Béar, $-5 \mathrm{~m}$. Irradiance: $11000 \mathrm{cal} \mathrm{cm}^{2}$ year ${ }^{-1}$. Experiment started on 15 June 1976. Only 6 days later, the colonies were covered by a yellowish mucous veil, probably decaying. After 35 days, the bare skeletons remained, and all animals were dead.

ii. Cap Béar, $-10 \mathrm{~m}$. Irradiance: $5100 \mathrm{cal} \mathrm{cm}^{-2}$ year ${ }^{-1}$. Experiment started on 15 June 1976. After 6 days, the colonies were alive and healthy. After 35 days, only one colony had survived, but it was dead one month later.

iii. Cap Béar, $-20 \mathrm{~m}$. Irradiance: $1375 \mathrm{cal} \mathrm{cm}^{-2}$ year ${ }^{-1}$. Experiment started on 15 June 1976. During the first 164 days of the experiment, the branches remained all alive. On 6 December 1977 (after 539 days) the colonies had disappeared.

iv. Cap Rédéris, in crevice under isolated boulder, $-25 \mathrm{~m}$. Irradiance: $20 \mathrm{cal} \mathrm{cm}^{-2} \mathrm{year}^{-1}$. Experiment started on 14 June 1976. The branches stayed alive for 127 days, after which observations were terminated.

v. Cap Rédéris, at the foot of a vertical wall, $-24 \mathrm{~m}$. Irradiance: $100 \mathrm{cal} \mathrm{cm}^{-2}$ year ${ }^{-1}$. Experiment started on 14 June 1976. After 127 days, only one branch had disappeared, all remaining branches being alive and healthy. On 16 June 1978 (two years after the experiment was started) one branch was still in place and alive, its polyps healthy and active.

\section{Lophogorgia ceratophyta}

Only a few colonies of this species were transplanted with the stones of the third experimental series. The numbers are too low to give a reliable insight into the tolerances of these animals, but the results are reported for completeness' sake.

i. Ile Grosse, on the concrete pipe transporting seawater to the laboratory aquarium, $-3 \mathrm{~m}$. Irradiance: $16500 \mathrm{cal} \mathrm{cm}^{-2}$ year-1. Experiment started on 9 December 1977, with only one branch of Lophogorgia, which was found dead, smothered by algal turf, 193 days later.

ii. Grotte de Béar, $-3 \mathrm{~m}$. Irradiance: $80 \mathrm{cal} \mathrm{cm}^{-2}$ year ${ }^{-1}$. Experiment started on 9 December 1977 with one branch, which had died upon the next inspection, 194 days later.

iii. Cap Béar, $-20 \mathrm{~m}$. Irradiance: $1375 \mathrm{cal} \mathrm{cm}^{-2}$ year ${ }^{-1}$. Experiment started on 9 December 1977 with 5 branches. After 195 days, 4 branches were still alive, and average growth was $28.5 \mathrm{~mm}$ year ${ }^{-1}$.

iv. Cap Rédéris, under overhanging rock, $-26 \mathrm{~m}$. Irradiance: $8 \mathrm{cal} \mathrm{cm}^{-2} \mathrm{year}^{-1}$. Experiment started on 9 December 1977 with 2 colonies (total of 5 branches). One colony was damaged by sediment, the other one, with 3 branches, had grown at an average rate of $21.6 \mathrm{~mm}^{-1}$ year $^{-1}$ during the 192 days of the experiment.

\section{CONCLUSIONS AND DISCUSSION}

Although some interesting results have been obtained, the entire set of experiments was rather frustrating as a result of destruction of experimental stations, ineffectiveness of clamps and clothespegs, and the disappearance of branches due to unknown causes.

As compared with the experiments involving concrete blocks and PVC-racks, the transplantation of rocks with naturally attached animals ran rather smoothly. The stones and the metal racks used were heavy enough to remain in place, although the shallow ones needed attachment with nylon rope. Disappearance of colonies was due to natural causes, and not to ineffectiveness of some manmade mechanism. Moreover, undamaged colonies were used, and growth rates not affected by other factors than changes in physical environment. I therefore strongly recommend that biologists wishing to undertake transplantation experiments under water try to transplant their organisms together with the natural substrata, as this is the easiest method with the best interpretable results. As was mentioned in section II, colonies of each species came from one depth only. Although it cannot be excluded that some depth adaptation occurs, I believe that this cannot have been of strong influence on the experiments. In spite of the many frustrations my experiments led to some interesting results, which I will give per species. It must be noted that none of the gorgonians survived in the surf zone, which corresponds to my observations on natural populations (Weinberg, 1978, 1979a). 
This fact was also reported for Fijian sea fans by Muzik \& Wainwright (1977). In the Caribbean, on the other hand, several species (e.g., Gorgonia spp., Pterogorgia spp.) thrive in this zone (personal observations).

\section{Eunicella singularis}

The natural occurrence of the species is in places with irradiance values of 30 to $10000 \mathrm{cal} \mathrm{cm}^{-2}$ year $^{-1}$ (Weinberg, 1979a). In my experiments, transplanted branches survived and grew in irradiance conditions ranging from 8 to $20000 \mathrm{cal}$ $\mathrm{cm}^{-2}$ year $^{-1}$. The fact that colonies are able to grow under extremely dark conditions is interesting, since these animals contain symbiotic zooxanthellae. Apparently, this symbiosis is of no vital importance to $E$. singularis, which explains the existence of a form without zooxanthellae, called $E$. singularis apbyta (cf. Théodor, 1969). The phenomenon that animals are not encountered in such dark places in nature resides in the photopositive behaviour of the planula larvae of this species (Weinberg, 1979b). Adult colonies are not found in shallow waters under natural conditions, and attempts to transplant them to shallow waters also failed. Experiments such as described in section III.1.b.i to iv yield some explanations why. Irradiance conditions do not seem to be lethal. However, abrasion in the surf zone, and wearing or overgrowing by algae are harmful to the species, especially juvenile colonies. Therefore, if larvae reach these upper layers and are able to settle before being swept away, their chances of survival are very reduced. The best growing branches in depths of less than $5 \mathrm{~m}$ occurred in the shallowest station, namely in the rear of the Grotte de Béar, at $1 \mathrm{~m}$ depth. Water conditions are turbulent here, but because of the reduced light conditions $(13 \mathrm{cal}$ $\mathrm{cm}^{-2}$ year-1) there is no algal competition. It is perhaps significant that near this very spot the only naturally growing colony in depths of less than $5 \mathrm{~m}$ was found (Weinberg, 1979a).

In some places, branches suffered heavily by burial or abrasion from debris or sediment. In nature, on the other hand, it is not rare to find extremely healthy colonies fixed upon some hard substratum (rock, shell, etc.) covered by a thick (up to $5 \mathrm{~cm}$ ) layer of sand or mud. It is not clear how these colonies survive in such an environment, especially during their younger phases, since even if the hard substrata mentioned are laid bare during brief periods, favouring settlement of planula larvae on these virgin surfaces, for most of the year these places are covered by a layer of sediment.

\section{Paramuricea clavata}

The species is encountered in nature under irradiance conditions ranging from 120 to $330 \mathrm{cal}$ $\mathrm{cm}^{-2}$ year ${ }^{-1}$ (Weinberg, 1979a). Transplantations show a much wider tolerance to light: 8 to 5100 cal $\mathrm{cm}^{-2}$ year $^{-1}$. Above $10 \mathrm{~m}$ depth, in strong sunlight, the colonies will invariably die, probably due to light itself, but also due to abrasion in turbulent waters and algal competion. As a whole, since the transplanted branches display a tolerance not reflected by the natural niche of the species, it must be supposed that selectivity of the larvae, with a probable preference for vertical, sedimentfree surfaces, and tolerances of juvenile colonies cause the ecological distribution typical for this species (see Weinberg, 1979a). It is puzzling why growth rates were so slow within a natural population of Paramuricea (section III.2.b.ix), whereas under some unnatural conditions (sections III.2.a.iii and III.2.b.viii) the transplants were very successful. The physiological optimum apparently does not coincide with the ecological niche of the species.

\section{Corallium rubrum}

This sciaphilous species, found in irradiance conditions below $130 \mathrm{cal} \mathrm{cm}^{-2} \mathrm{year}^{-1}$ in nature (Weinberg, 1979a) cannot survive where light is too strong. The experiment described in section III.3.i is very important in this respect. The colonies transplanted to shallow water survived only a few days. This was not due to turbulence, since the weather remained calm during this period, neither were the branches affected by algal growth. Temperature can also be ruled out, since the species survives in the aquarium of the Laboratoire Arago in Banyulssur-Mer, where the seawater supply comes from similar depths. Moreover, the species thrives in Corsican and Sardinian waters, where temperature conditions at $20 \mathrm{~m}$ depth are comparable to those in Banyuls at the surface. Even at $10 \mathrm{~m}$ depth, in 
irradiance conditions of $5100 \mathrm{cal} \mathrm{cm}^{-2} \mathrm{year}^{-1}$, the colonies soon died. However, at $20 \mathrm{~m}$ depth, in $1375 \mathrm{cal} \mathrm{cm}^{-2}$ year $^{-1}$ survival is possible, although I never observed colonies of $C$. rubrum occurring in nature under similar conditions. The larvae of this species are indifferent to light (Weinberg, 1979b), and this experiment indicates that tolerance of the colonies plays an important role in determining the ecological niche. Juvenile colonies may even be more sensitive to light, or sedimentation, since C. rubrum thrives under overhanging walls and in caves or small holes. The geonegative behaviour of the larvae (De Lacaze-Duthiers, 1864; Weinberg, 1979b) may be very important in this respect.

\section{Lophogorgia ceratophyta}

Occurring deeper than $10 \mathrm{~m}$ in nature (Weinberg, 1979a), transplanted branches reacted as follows. Dying in shallow stations, probably due to turbulence, abrasion and algal competition, the branches maintained high growth rates in deeper stations, regardless of irradiance conditions. Tolerances of the adult colonies seem to dictate natural distribution patterns.

\section{ACKNOWLEDGEMENTS}

Je remercie M. Jacques Soyer, Directeur du Laboratoire Arago, Banyuls-sur-Mer, pour les facilités d'hébergement et de travail dont $\mathrm{j}$ 'ai bénéficié à plusieurs reprises. Ce long travail n'aurait pas été possible sans l'équipage du "RUFI", qui m'a conduit si souvent vers mes divers stations et a assuré ma sécurité: je remercie sincèrement $\mathrm{MM}$. Jacques Centelles et Germain Vilasèque. Finalement, l'aide efficace et amicale des plongeurs du laboratoire, MM. Jean Mabit et Gérard Boyer, m'a toujours été précieuse. Mr. Herman Mittelberg (Institute of Taxonomic Zoology, Amsterdam) made the clamps and racks for these experiments; I thank him for his skill and his patience. Many friends helped in installing branches under water, or carrying out measurements: I thank my wife Francisca, Jean-Michel Amouroux, Henk Albus and Charlotte van Duijl. Prof. Dr. Jan H. Stock and Prof. Dr. C. den Hartog are acknowledged for their critical review of the manuscript. I am grateful to Dr. Ian R. Ball for reviewing my English text. This work was carried out under grant 87-117 from the Netherlands' Organization for the Advancement of Pure Research (Z.W.O.).

\section{REFERENCES}

BAK, R. P. M., 1975. Ecological aspects of the distribution of reef corals in the Netherlands Antilles. Bijdr. Dierk., 45 (2): 181-190.

Barletta, G., R. Marchetti \& M. Vighi, 1968. Ricerche sul corallo rosso, 4. Ulteriori osservazioni sulla distribuzione del corallo rosso nel Tirreno. Rc. Ist. lomb. Sci. Lett., 102 (B): 119-144.
Benayahu, Y. \& Y. LOYA, 1977. Space partitioning by stony corals, soft corals and benthic algae on the coral reefs of the northern Gulf of Eilat (Red Sea). Helgoländ. wiss. Meeresunters., 30: 362-382.

Boutler, J., L. CABIoch \& J.-R. Grall, 1974. Quelques observations sur la pénétration de la lumière dans les eaux marines au voisinage de Roscoff et ses conséquences écologiques. Bull. Soc. phycol. France, 19: 129-140.

Burla, H., B. Pabst \& W. Stahel, 1976. Vorkommen von Astropecten aranciacus (Asteroidea, Echinodermata) in Abhängigkeit von Umweltbedingungen. Helgoländ. wiss. Meeresunters., 28: 167-182.

CAMP, J., 1976. Comunidades bentónicas de sustrato duro del litoral NE. Español, 4. Poliquetos. Invest. Pesq., 40 (2): 533-550.

Carpine, C. \& M. Grasshoff, 1975. Les gorgonaires de la Méditerranée. Bull. Inst. océanogr. Monaco, 71 (1430): 1-140.

Castric-Fey, A., A. Girard-Descatoire, F. Lafargue \& M.-T. I'HARdY-Halos, 1973. Etagement des algues et des invertébrés sessiles dans l'archipel de Glénan. Définition biologique des horizons bathymétriques. Helgoländ. wiss. Meeresunters., 24: 490-509.

Chardy, P., 1970. Ecologie des Crustacés Péracarides des fonds rocheux de Banyuls-sur-Mer. Amphipodes, Isopodes, Tanaidacés, Cumacés, infra- et circalittoraux. Vie Milieu, 21 (3B): 657-727.

DANA, T. F., 1976. Reef-coral dispersion patterns and environmental variables on a Caribbean coral reef. Bull. mar. Sci., 26 (1): 1-13.

Done, T. J., 1977. A comparison of units of cover in ecological classifications of coral communities. Proc. 3rd int. Coral Reef Symp., Miami: 9-14.

Duclaux, G. \& F. Lafargue, 1972. Madréporaires de Méditerranée occidentale. Recherche des zooxanthelles symbiontiques. Compléments morphologiques et écologiques. Vie Milieu, 23 (1A): 45-63.

FredJ, G., 1972. Compte rendu de plongée en S.P. 300 sur les fonds à Laminaria rodriguezii Bornet de la Pointe de Revellata (Corse). Bull. Inst. océanogr. Monaco, 71 (1421): 1.42.

GAMULIN-BridA, H., 1974. Biocoenoses benthiques de la Mer Adriatique. Acta adriat., 15 (9): 1-102.

GeIsTer, J, 1977. The influence of wave exposure on the ecological zonation of Caribbean coral reefs. Proc. 3rd internat. Coral Reef Symp., Miami: 23-29.

GrigG, R. W., 1974. Distribution and abundance of precious corals in Hawaii. Proc. 2nd internat. Coral Reef Symp., Brisbane: $235-240$.

HARMELIN, J.-G., 1969. Bryozoaires des grottes sous-marines obscures de la région marseillaise. Faunistique et écologie. Téthys, 1 (3): 793-806.

Hoek, C. van den, A. M. Cortel-Breeman \& J. B. W. WANDERS ,1975. Algal zonation in the fringing reef of Curaçao, Netherlands Antilles, in relation to zonation of corals and gorgonians. Aquat. Bot., 1: 269-308.

Jaubert, J., 1972. Benthos: étude et mesure d'un facteur écologique: l'éclairement. Réalisation d'un appareil enregistreur. Téthys, 3 (2): 205-246.

JAUbert, J. \& P. VASSEUR, 1973. Essai d'interprétation de la répartition de certains peuplements sciaphiles du Grand Récif de Tuléar (Madagascar) à partir d'enregistrements des variations de l'éclairement. C. R. Acad. Sc. Paris, 276 (D): 2059-2062. 
- \& — 1974. Light measurements: duration aspect and the distribution of benthic organisms in an Indian Ocean coral reef (Tuléar, Madagascar). Proc. 2nd internat. Coral Reef Symp., Brisbane: 127-142.

KINZIE, R. A., 1973. The zonation of West Indian gorgonians. Bull. mar. Sci., 23 (1): 93-155.

LABOREL, J. \& J. VACELET, 1961. Répartition bionomique du Corallium rubrum Lmck dans les grottes et falaises sousmarines. Rapp. P.-v. Réun. Commn. int. Explor. scient. Mer Méditerr., 16 (2): 465-469.

LACAZE-DUTHIERS, H. DE, 1864. Histoire naturelle du corail. Organisation, reproduction, pèche en Algérie, industrie et commerce: i-xxv, 1-371, $20 \mathrm{pls}$ (J. B. Baillière et Fils, Paris).

LAUbier, L., 1966. Le coralligène des Albères. Monographie biocénotique. Annls. Inst. océanogr., Paris, 43 (2): 139 316.

LEwIS, J. B. ,1974. Settlement and growth factors influencing the contagious distribution of some Atlantic reef corals. Proc. 2nd internat. Coral Reef Symp., Brisbane: 201-206.

LoYA, Y., 1972. Community structure and species diversity of hermatypic corals at Eilat, Red Sea. Mar. Biol., 13: 100-123.

Muzik, K. \& S. WAINWRight, 1977. Morphology and habitat of five Fijian sea fans. Bull. mar. Sci., 27 (2): 308-337.

REYSS, D., 1971. Les canyons sous-marins de la mer Catalane, le Rech du Cap et le Rech Lacaze-Duthiers, 3. Les peuplements de macrofaune benthique. Vie Milieu, 22 (3B) : 529-613.

Riedl, R., 1966. Biologie der Meereshöhlen: 1-636 (P. Parey, Hamburg/Berlin).

Roos, P. J., 1964. The distribution of reef corals in Curaçao. Stud. Fauna Curaçao, 20 (81): 1.51, 13 pls.

- 1967. Growth and occurrence of the reef coral Porites astreoides Lamarck in relation to submarine radiance distribution: 1-72 (Ph. D. Thesis, University of Amsterdam). (Elinkwijk, Utrecht).

RoushDY, H. M., 1962. Expansion of Alcyonium digitatum L. (Octocorallia) and its significance for the uptake of food. Vidensk. Medd. Dansk naturh. Foren., 124: 409.420 .

SCHMIDT, H., 1972. Bionomische Studien an mediterranen Anthozoen: die Anthozoenfauna des Strombolicchio (Äolische Inseln). Mar. Biol., 15: 265-278.

SCHUHMACHER, H., 1973. Die lichtabhängige Besiedlung von
Hafenstützpfeilern durch sessile Tiere und Algen aus dem Korallenriff bei Eilat (Rotes Meer). Helgoländ. wiss. Meeresunters., 24: 307-326.

THÉODOR, J., 1969. Contribution à l'étude des gorgones, 8. Eunicella stricta aphyta sous-espèce nouvelle sans zooxanthelles, proche d'une espèce normalement infestée par ces algues. Vie Milieu, 20 (3A): 635-638.

True, M. A., 1970. Etude quantitative de quatre peuplements sciaphiles sur substrat rocheux dans la région marseillaise. Bull. Inst. océanogr. Monaco, 69 (1401): $1-48$.

WEDLER, E., 1975. Ökologische Untersuchungen an Hydroiden des Felslitorals von Santa Marta (Kolumbien). Helgo!änd. wiss. Meeresunters., 27: 324-363.

WeInberg, S., 1975. Ecologie des Octocoralliaires communs du substrat dur dans la région de Banyuls-sur-Mer. Essai d'une méthode. Bijdr. Dierk., 45 (1): 50-70.

- 1978. Mediterranean octocorallian communities and the abiotic environment. Mar. Biol., 49 (1): 41.57.

1979a. Autecology of shallow-water Octocorallia from Mediterranean rocky substrata, 1. The Banyuls area. Bijdr. Dierk., 49 (1): 1-15.

- 1979b. The light-dependent behaviour of planula larvae of Eunicella singularis and Corallium rubrum and its implication for octocorallian ecology. Bijdr. Dierk., 49 (1): $16-30$

Weinberg, S. \& A. Cortel-Breeman, 1978. The estimation of the yearly cycle of submarine irradiance for ecological purposes. A methodological example based on data from Banyuls-sur-Mer (France). Bijdr. Dierk., 48 (1): 35-44.

WIEDENMAYER, F., 1977. Shallow-water sponges of the Western Bahamas. Experientia, Suppl., 28: 1-287, 43 pls. (Birkhäuser, Basel/Stuttgart).

ZANDER, C. D. \& A. HeYMER, 1970. Tripterygion tripteronotus (Risso, 1810) und Tripterygion xanthosoma n. sp. Eine ökologische Speziation (Pisces, Teleostei). Vie Milieu, 21 (2A): 363-394.

- \& - 1977. Analysis of ecological equivalents among littoral fish. In: B. F. KeEgan, P. O. CeIDIGH \& P. J. S. BOADEN eds., Biology of benthic organisms: 621.630 (Pergamon Press, Oxford/New York).

ZANDER, C. D. \& H. JelineK, 1976. Zur demersen Fischfauna im Bereich der Grotte von Banjole (Rovinj/YU) mit Beschreibung von Speleogobius trigloides n. gen. n. sp. (Gobiidae, Perciformes). Mitt. Hamburg. zool. Mus. Inst., 73: 265-280. 